\title{
Dengue viruses in Brazil, 1986-2006
}

\author{
Rita Maria Ribeiro Nogueira, ${ }^{1}$ Josélio Maria Galvão de Araújo, ${ }^{1}$ \\ and Hermann Gonçalves Schatzmayr ${ }^{1}$
}

Suggested citation

Nogueira RMR, Araujo JMG, Schatzmayr HG. Dengue viruses in Brazil, 1986-2006. Rev Panam Salud Publica. 2007;22(5):358-63.

\begin{abstract}
A total of 4243049 dengue cases have been reported in Brazil between 1981 and 2006, including 5817 cases of dengue hemorrhagic fever/dengue shock syndrome (DHF/DSS) and a total of 338 fatal cases. Although all Brazilian regions have been affected, the Northeast and Southeast regions have registered the highest number of notifications. DENV-1 and DENV-4 were isolated for the first time in the Amazon region of Brazil in 1981 and 1982. The disease became a nationwide public health problem following outbreaks of DENV-1 and DENV-2 in the state of Rio de Janeiro in 1986 and 1990, respectively. The introduction of DENV-3 in 2000, also in the state of Rio de Janeiro, led to a severe epidemic with 288245 reported dengue cases, including 91 deaths. Virus strains that were typed during the 2002 epidemic show that DENV-3 has displaced other dengue virus serotypes and entered new areas, a finding that warrants closer evaluation.

Unusual clinical symptoms, including central nervous system involvement, have been observed in dengue patients in at least three regions of the country.
\end{abstract}

Key words Dengue, dengue/epidemiology, dengue virus/classification, diagnosis, genome, Brazil.

The high level of dengue virus activity on the American continent and the reinfestation of Brazil by the Aedes aegypti vector in 1977 contributed to the reintroduction of the dengue viruses (DENV) into Brazil in the 1980s $(1,2)$. Since that time, more than $60 \%$ of the reported cases of dengue in the Region of the Americas have occurred in Brazil (Figure 1). In this article, we describe the introduction of dengue viruses in Brazil, the virus strains, and

\footnotetext{
Flavivirus Laboratory, Department of Virology, Instituto Oswaldo Cruz/ FIOCRUZ, Avenida Brasil 4365, 21040-190, Rio de Janeiro, RJ, Brasil. E-mail: rita@ioc.fiocruz.br.
}

spread of the disease to different regions of the country.

A dengue outbreak caused by the DENV-1 and DENV-4 viruses (19811982) occurred in the city of Boa Vista, in the state of Roraima, in the Amazon region close to the Venezuelan border (3). This outbreak was contained by local vector control measures and no dengue activity was reported for the next four years in Brazil. It was only after 1986, with the DENV-1 virus introduction into the state of Rio de Janeiro (4), that dengue infections became a nationwide public health problem. Difficulties implementing effective vector control programs in large urban communities resulted in the rapid spread of the virus and explosive virgin soil epidemics in several states. The situation was aggravated in 1990 by the introduction of DENV-2 virus, also into the state of Rio de Janeiro (5). With its subsequent spread to other regions of the country, there were more severe clinical presentations and the first fatal cases due to secondary infections.

Absent from the Americas for almost 15 years, DENV-3 was reintroduced in 1994 (6), reaching Brazil by 2000 where it caused a widespread and severe dengue epidemic in the summer of 2001-2002 (7-9). 
FIGURE 1. Reported dengue cases in Brazil and the Region of the Americas, 1995-2006

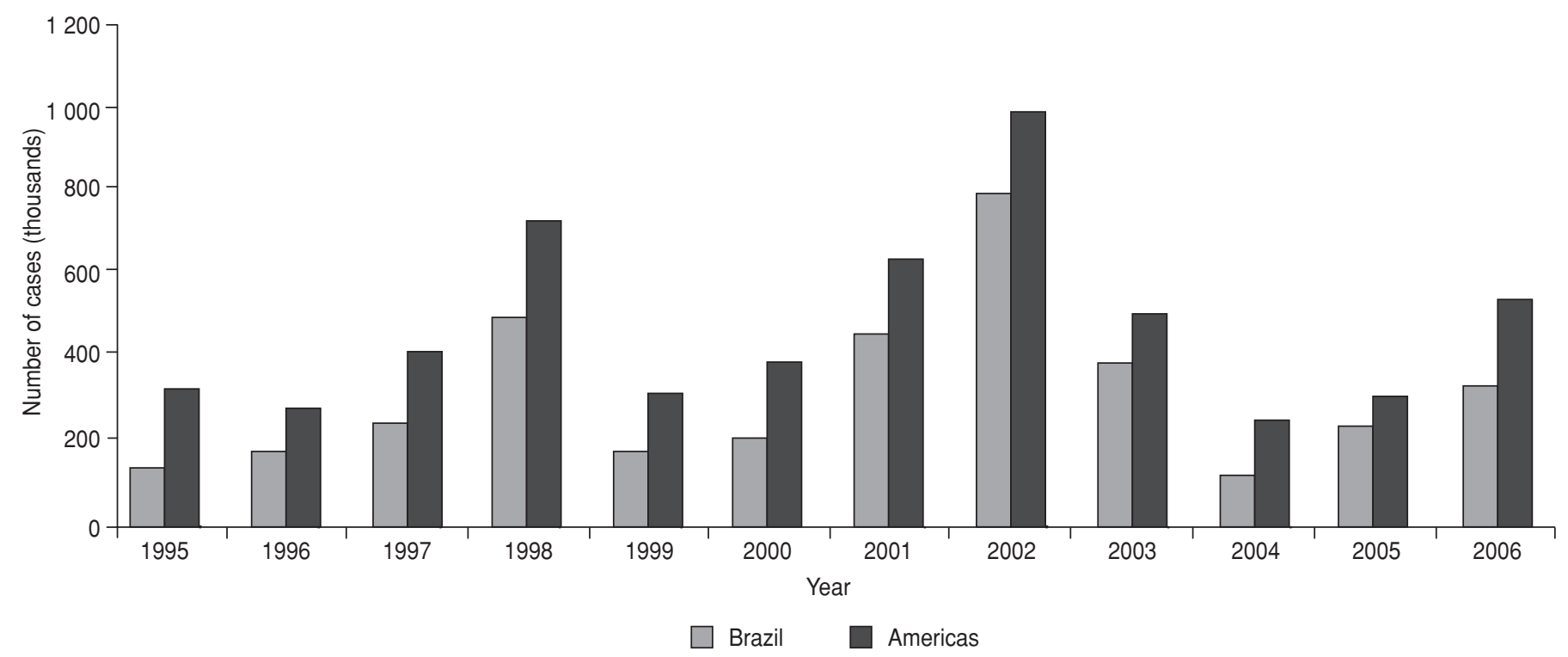

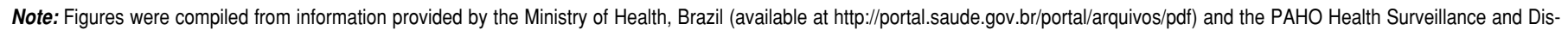
ease Management Web site (available at: http://www.paho.org/english/ad/dpc/cd/dengue.htm).

The three dengue virus serotypes spread successively throughout the country and by the end of 2006, 25 of the 27 Brazilian states had reported dengue epidemics. A total of 4243049 reported cases in the last 20 years in Brazil were caused by DENV-1, DENV-2, and DENV-3 circulation (10).

\section{Dengue in the State of Rio de Janeiro}

The state of Rio de Janeiro was the site of the introduction and dissemination of DENV-3, a new serotype in the country, as well as DENV-1 and DENV-2, making it obvious that this area is important for dengue epidemiology in Brazil. As an important tourist center with high levels of $A e$. aegypti infestation, the area merits close attention in terms of entry of dengue viruses into Brazil.

Dengue infection was first confirmed in the state of Rio de Janeiro by the Flavivirus Laboratory at the Oswaldo Cruz Institute in April 1986. The DENV-1 virus was isolated from patients presenting with exanthematic disease during an explosive epidemic in the municipality of Nova Iguaçu (4). This municipality belongs to the Greater Metropolitan Area of the state, which includes the capital Rio de Janeiro and 20 other municipalities, and has a population of over 11 million out of the state's 14.7 million total. Nova Iguaçu is located about $25 \mathrm{~km}$ from downtown Rio de Janeiro, with a large population that commutes daily to surrounding areas. This heavy circulation of people facilitated the rapid spread of dengue virus to susceptible populations, causing an epidemic of approximately 92000 cases reported during the 1986-1987 period (11). The infections were clinically characterized as classic dengue fever. The only fatality reported as a result of this episode was that of a young patient.

From Rio de Janeiro, the virus spread rapidly along the coast to different states, all previously infested with the vector. Epidemics in these areas presented similar characteristics to that of Rio de Janeiro: only DENV-1 was involved and no severe cases of dengue hemorrhagic fever (DHF) or dengue shock syndrome (DSS) were reported.
By April 1990, an active surveillance program established by the municipality of Niterói in the Rio de Janeiro Greater Metropolitan Area allowed for early identification of DENV-2 during a period of high DENV-1 virus activity, exactly four years after the first DENV-1 strain isolations. The epidemic in 1990-1991 presented two waves and a significantly higher proportion of patients with thrombocytopenia and clinical presentations requiring hospitalization were seen in the period when DENV-2 was predominant (5).

Both the DENV-1 and DENV-2 viruses were isolated during an epidemic recognized in 1995-1996, with a total of 51465 reported cases of dengue fever. In January 1998 a new epidemic occurred in the Paraíba river valley, in the western part of the state of Rio de Janeiro and quickly spread to other municipalities, including an important tourist area on the northern coast (11). DENV-2 spread from Rio de Janeiro to different parts of the country, showing more severe clinical presentations in comparison with the previous DENV-1 outbreaks. 
Because of the epidemiological importance of the state of Rio de Janeiro, a virological surveillance program was mounted in the city of Nova Iguaçu over the years, including during periods between epidemics. This made it possible to isolate a strain of the DENV-3 virus in 2000 from a case of classic dengue fever as well as from the vector Ae. aegypti collected in the field $(7,8,12)$.

DENV-3 virus introduction increased the number of reported cases to 69269 in 2001 and during the summer of 2002, DENV-3 caused the most severe epidemic so far observed in the state of Rio de Janeiro $(8,9)$. The number of cases in 2001-2002 exceeded the epidemic of 1990-1991, when about 100000 cases with 462 DHF/DSS cases and 8 deaths were reported. In the DENV-3 epidemic in the summer of 2002, a total of 288245 cases were reported, with 1831 cases of DHF/DSS and 91 deaths, corresponding to 1735 reported cases per 100000 inhabitants (9). The highest notification of cases was in the Greater Metropolitan Area of the state.

Laboratory studies carried out in 2000/2001 on 1478 reported dengue cases confirmed a $54.5 \%$ infection rate by serology and/or virus isolation and polymerase chain reaction (RT-PCR) (8). Three DENV-1, one DENV-2, and 320 DENV-3 strains were detected, revealing that DENV-3 represented $98.7 \%$ of the circulating viruses during the 2002 epidemic in the state of Rio de Janeiro. Forty fatal cases were confirmed for DENV-3 by our institution and at least two different laboratory methodologies were used on 20 of these cases. DENV-3 was the only serotype detected in these fatal cases and virtually all of them were primary infections by DENV-3 (9).

\section{Dengue viruses in other Brazilian states}

The southeastern and northeastern regions of Brazil have been the most affected by dengue infections, with epidemics occurring almost yearly. In the southeastern region, besides Rio de Janeiro, the states of Minas Gerais and Espírito Santo have reported epidemics in both the state capitals and inland municipalities. In the state of São Paulo, dengue virus activity was mainly observed in inland municipalities, with some severe epidemics and sporadic activity in coastal locations.

The northeastern region, an important tourist area comprising seven states along the coast, has suffered successive dengue epidemics and was responsible for the highest number of dengue notifications during the late 1990s. In 1994, the state of Ceará reported an epidemic with 47889 cases, including 25 cases of DHF and 12 deaths. An increase in DHF was observed in 2003, when 23796 dengue cases were reported, including 291 DHF cases and 20 deaths. This scenario was also observed in 2005 with 22817 cases reported, including 195 DHF cases and 20 deaths (13-16).

The midwestern region, which includes the Federal District and the nation's capital Brasília, confirmed DENV-1 circulation in 1990. In 1995 DENV-2 was isolated and one case of dual infection was reported (17).

Dengue epidemics caused by DENV-2 occurred in the state of Tocantins in 1991 (18) and in the state of Pará in 1995 (19), both in Brazil's northern region. The state of Roraima confirmed dengue activity in 1996, 14 years after the first outbreak occurred in that area. In 1998, the state of Amazonas reported a dengue epidemic with 23910 cases. In 2001, all the states in the Amazonas region had epidemics of different magnitudes (10), including Acre and Amapá, confirming the expansion of Ae. aegypti in the Amazon basin.

In the southern region, the state of Paraná is the only one that has reported dengue since 1995. No autochthonous cases were reported in 2006 in the states of Santa Catarina or Rio Grande do Sul (10).

It should be emphasized that, according to available epidemiological data, dengue infections in the country are found in all age groups in the period studied, with no predominance in children.

\section{Genetic characterization of dengue viruses}

The co-circulation of DENV-1 and DENV-2 in Brazil began in 1990 with the subsequent appearance of DHF/ DSS and fatal cases (Figure 2). This occurred initially in Rio de Janeiro and later in other states $(5,20-22)$. An increase in the number of more severe cases in Brazil, similar to other countries of the Americas, coincided with the introduction of the DENV-2 Southeast Asian genotype into the continent (23).

Analysis by genome sequencing performed on DENV-1 and DENV-2 isolated in Brazil identified genotypes from the Americas and Southeast Asia of DENV-1 and DENV-2, respectively (24-26). The complete nucleotide sequence analysis in our laboratory of one Brazilian DENV-2 isolated in 1998 confirmed that the Southeast Asian genotype III is circulating in Brazil (27).

The DENV-3 genotype introduced into the continent has been associated with major DHF/DSS epidemics in Sri Lanka and India and with DHF/ DSS cases and deaths in Mexico and Central American countries $(28,29)$. DENV-3 strains isolated in Rio de Janeiro in 2000, 2001, 2002, and 2003 have been sequenced by our group and in one strain the complete genome was detailed (GenBank accession no. AY679147), confirming that this strain corresponds to genotype III of the Indian subcontinent (30-32).

The data on dengue strain typing after introduction of DENV-3 show that this genotype dislodged other serotypes when first introduced into the area, showing its high infection capacity in both humans and vectors. These data however, need more careful evaluation and comparison with epidemiological data from other countries in the Region of the Americas.

\section{Clinical symptoms}

Besides the usual symptoms of dengue observed in the cases of DHF/ DSS, unusual manifestations involving the central nervous system were 
FIGURE 2: Number of DHF/DSS cases and deaths resulting from dengue infections reported in Brazil, 1990-2006

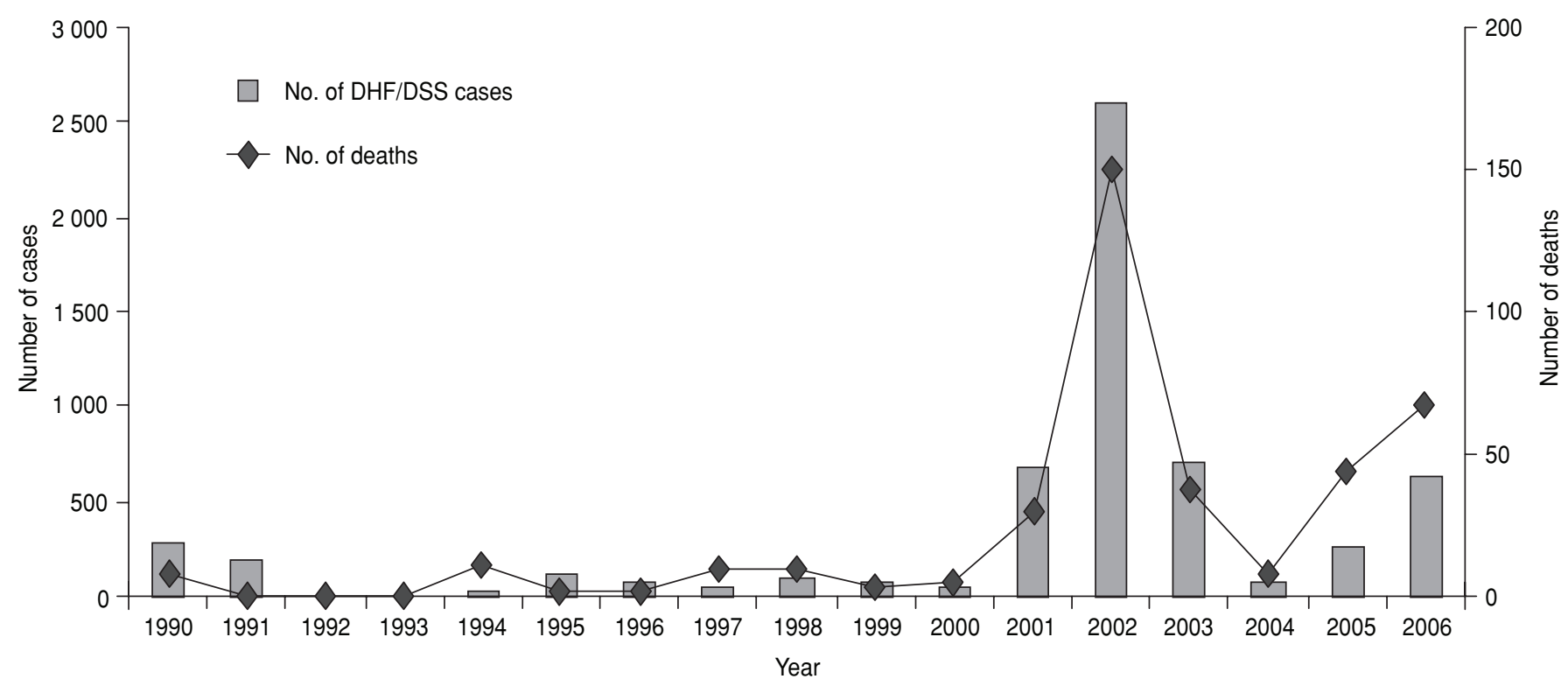

Source: Ministry of Health, Brazil, http://portal.saude.gov.br/portal/arquivos/pdf

reported during the 1986-1987 epidemic in Rio de Janeiro and later in different states, including one case in which the dengue antigen was detected in neuronal cells by immunohistochemistry (33-36). Neurological manifestations in 41 patients were reported in the state of Pernambuco between March and July 1997 and February and May 2002. The brain was involved in 5 of 7 of these cases in 1997 and 20 of 34 cases in 2002; the spinal cord was involved in 2 of 34 cases in 2002; peripheral nerves were involved in 2 of 7 cases in 1997 and 12 of 34 cases in 2002. Cerebral hemorrhage and acute disseminated encephalomyelitis were also diagnosed $(16,37)$.

In the state of Rondonia, acute encephalomyelitis was observed in 51 patients presenting signs and symptoms of dengue from November 2004 to March 2005. Anti-dengue IgM antibodies were detected in sera, and one patient, in whom the RT-PCR test detected DENV-3, presented IgM in cerebrospinal fluid $(38,39)$.

Dengue cases with high levels of serum aminotransferases have also been observed. Yellow fever infections were occasionally suspected but not confirmed by epidemiologic investigations and laboratory results.

During the DENV-3 epidemic in Rio de Janeiro in 2002, viral RNA was detected in the cerebrospinal fluid, liver, brain, lung, spleen, and kidneys of fatal cases by RT-PCR (9).

\section{CONCLUSIONS}

Dengue virus activity in Brazil during the past 20 years is demonstrated by the high number of reported cases and states involved in epidemics. The co-circulation of three dengue serotypes is responsible for the increased occurrence of severe forms of the disease, such as DHF/DSS.

The presence of Ae. aegypti in about $80 \%$ of the country and the difficulties of implementing successful vector control are well-known in Brazil and in many other countries in the region. Barriers to adequate vector control include poor urban planning, demographic pressure, and the shortage of vector surveillance and personnel able to cover huge geographic areas.
While vector control continues to be difficult, progress has been made in notification of dengue outbreaks in Brazil. A network of laboratories that are capable of diagnosing dengue infections has been established in all states of Brazil, under the supervision of Reference Laboratories at the regional level.

Considering the widespread presence of the disease vector and the lack of a vaccine to prevent dengue infections, constant improvement in the rapid identification and correct clinical management of dengue cases by health services is crucial in order to reduce the impact of the disease and the number of fatal cases.

Acknowledgments. The authors would like to thank the Conselho Nacional de Desenvolvimento Científico e Tecnológico (grant No. 501564/03-9) and Fundação de Amparo a Pesquisa Científica e Tecnológica (grant No. E$26 / 152.490 / 2002$ ) for their financial support of this work. We are also grateful to the Brazilian Ministry of Health and the Rio de Janeiro State Health Secretariat for providing epidemiological data. 


\section{REFERENCES}

1. Pinheiro FP, Corber SJ. Global situation of dengue and dengue hemorrhagic fever and its emergence in the Americas. World Health Stat Q. 1997;50(3-4):161-9.

2. Gubler DJ. Dengue/dengue hemorrhagic fever in the Americas: prospects for the year 2000. In: Halstead SB, Gomez-Dantes H, eds. Dengue, a worldwide problem, a common strategy. Proceedings of an International Conference on dengue and Aedes aegypti community-based control. Mexico City: Ministry of Health; 1992. Pp. 19-27.

3. Osanai $\mathrm{CH}$, Travassos da Rosa APA, Tang AT, do Amaral RS, Passos AD, Tauil PL. Surto de dengue em Boa Vista em Roraima. Rev Inst Med Trop São Paulo. 1998;25(1):53-4.

4. Schatzmayr HG, Nogueira RMR, Travassos da Rosa APA. An outbreak of dengue virus at Rio de Janeiro-1986. Mem Inst Oswaldo Cruz. 1986;81(2): 245-6.

5. Nogueira RMR, Miagostovich MP, Lampe E, Souza RW, Zagne SMO, Schatzmayr HG. Dengue epidemic in the state of Rio de Janeiro, Brazil, 1990-1991: co-circulation of dengue 1 and dengue 2 serotypes. Epidemiol Infect. 1993;111(1):163-70.

6. U.S. Division of Health and Human Services, Centers for Disease Control and Prevention, Division of Vector-Borne Infectious Diseases, Dengue Branch, San Juan, Puerto Rico. Dengue 3 in Central America. Dengue surveillance. Summary. San Juan: CDC; 1995. 70 pages.

7. Nogueira RMR, Miagostovich MP, Filippis AMB, Pereira MAS, Schatzmayr HG. Dengue virus type 3 in Rio de Janeiro, Brazil. Mem Inst Oswaldo Cruz. 2001;96(7):925-6.

8. De Simone TS, Nogueira RMR, Araujo ESM, Guimarães FR, Santos FB, Schatzmayr HG, et al. Dengue virus surveillance: the cocirculation of DENV-1, DENV-2 and DENV-3 in the state of Rio de Janeiro. Trans R Soc Trop Med Hyg. 2004;98(9):553-62.

9. Nogueira RMR, Schatzmayr HG, Filippis AMB, Santos FB, Cunha RV, Coelho JO, et al. Dengue type 3, Brazil, 2002. Emerg Infect Dis. 2005;11(9): 1376-81.

10. Brazil. Ministério da Saúde. Buletim, Situação Epidemiologica do Dengue 2005. Accessed on 10 December 2005 at http://portal.saude. gov.br/portal/arquivos/pdf.

11. Nogueira RMR, Miagostovich MP, Schatzmayr HG, Araújo ESM, Santos FB, Filippis $A M B$, et al. Dengue in the State of Rio de Janeiro, Brazil, 1986-1998. Mem Inst Oswaldo Cruz. 1999;94(3):297-304.

12. Lourenço-de-Oliveira R, Honório NA, Castro MG, Schatzmayr HG, Miagostovich MP, Alves JCR, et al. Dengue virus type 3 (DEN-3) isolation from Aedes aegypti in the municipality of Nova Iguaçú, state of Rio de Janeiro. Mem Inst Oswaldo Cruz. 2002;97(6): 799-800.

13. Nogueira RMR, Miagostovich MP, Schatzmayr HG, Morais G, Cardoso FMA, Ferreira J, et al. Dengue type 2 outbreak in the south of the state of Bahia, Brazil: Laboratorial and epi- demiological studies. Rev Inst Med Trop São Paulo. 1995;37(6):507-10.

14. Cunha RV, Miagostovich MP, Petrola Z, Araújo ESM, Cortez D, Pombo V, et al. Retrospective study on dengue in Fortaleza, state of Ceará. Mem Inst Oswaldo Cruz. 1998;93(2): 155-9.

15. Cunha RV, Schatzmayr HG, Miagostovich MP, Barbosa AMA, Paiva FGP, Miranda $\mathrm{RMO}$, et al. Dengue epidemic in the state of Rio Grande do Norte, Brazil, in 1997. Trans R Soc Trop Med Hyg. 1999;93(3):247-9.

16. Cordeiro, MT. Dengue in the state of Pernambuco, Brazil: 1995-1997. Virological, clinical and epidemiological aspects. Virus Rev Res. 1997;2(2): 112-3.

17. Rocco IM, Barbosa ML, Kanomata EHN. Simultaneous infection with dengue 1 and 2 in a Brazilian patient. Rev Inst Med Trop São Paulo. 1998; 40(3):151-4.

18. Vasconcelos PFC, Travassos da Rosa ES, Travassos da Rosa APA. Epidemia de febre clássica de dengue causada pelo sorotipo $2 \mathrm{em}$ Araguaína, Tocantins, Brasil. Rev Inst Med Trop São Paulo. 1993;35(2):141-8.

19. Travassos da Rosa APA, Vasconcelos PFC, Travassos da Rosa ES, Rodrigues SG, Mondet $B$, Cruz ACR, et al. Dengue epidemic in Belém, Pará, Brazil, 1996-97. Emerg Infect Dis. 2000;6(3):298-301.

20. Zagne SMO, Alves VGF, Nogueira RMR, Miagostovich MP, Lampe E, Tavares W. Dengue haemorrhagic fever in the state of Rio de Janeiro, Brazil: a study of 56 confirmed cases. Trans R Soc Trop Med Hyg. 1994; 88(6):677-9.

21. Souza RW, Cunha RV, Miagostovich MP, Timbó MJ, Montenegro F, Pessoa ETFP, et al. An outbreak of dengue virus infection in the state of Ceará, Brazil. Mem Inst Oswaldo Cruz. 1995;90(3):345-6.

22. Vasconcelos PF, Menezes DB, Melo LP, Pessoa ETF, Rodrigues SG, Travassos da Rosa ES, et al. A large epidemic of dengue fever with dengue hemorrhagic cases in Ceará State, Brazil, 1994. Rev Inst Med Trop São Paulo. 1995;37(3):253-5.

23. Rico-Hesse R, Harrison LM, Alba Salas R, Tovar D, Nisalak A, Ramos C, et al. Origins of dengue type 2 viruses associated with increased pathogenicity in the Americas. Virology. 1997;230(2):244-51.

24. Rico-Hesse R. Molecular evolution and distribution of dengue viruses type 1 and 2 in nature. Virology. 1990;174(2):479-493.

25. Deubel V, Nogueira RMR, Drouet MT, Zeller M, Reynes J, Ma DQ. Direct sequencing of genomic cDNA fragment amplified by the polymerase chain reaction for molecular epidemiology of dengue 2 viruses. Arch Virol. 1993; 129(1-4):197-210.

26. Miagostovich MP, Nogueira RMR, Schatzmayr HG, Lanciotti RS. Molecular epidemiology of DENV-2 in Brazil. Mem Inst Oswaldo Cruz. 1998;93(5):625-6.

27. Santos FB, Miagostovich MP, Nogueira RMR, Schatzmayr HG, Riley LW, Harris E. Complete nucleotide sequence analysis of a Brazil- ian dengue type 2 virus strain (BR64022/98) Mem Inst Oswaldo Cruz. 2002;97(7):991-5.

28. Lanciotti RS, Lewis JG, Gubler DJ, Trent DW. Molecular evolution and epidemiology of dengue-3 viruses. J Gen Virol. 1994;75(1):65-75.

29. Figueroa R, Ramos C. Dengue virus (serotype 3) circulation in endemic countries and its reappearance in America. Arch Med Res. 2000;31(4):429-30.

30. Miagostovich MP, Santos FB, De Simone TS, Costa EV, Filippis AMB, Schatzmayr HG, et al. Molecular characterization of dengue viruses type 3 isolated in the state of Rio de Janeiro. Braz J Med Res. 2000;35(1):1-4.

31. Miagostovich MP, Nogueira RMR. Molecular characterization of dengue virus: studies of Brazilian strains. In: Williams CR, ed. Focus on genome research. New York: Nova Science Publishers; 2004. Pp. 81-131.

32. Miagostovich MP, Santos FB, Furnian TM, Guimarães FR, Costa EV, Tavares FN, et al. Complete genetic characterization of a Brazilian dengue virus type 3 strain isolated from a fatal outcome. Mem Inst Oswaldo Cruz. 2006;101(3):307-13.

33. Chimelli L, Dumas HM, Barreto Neto M, Grandelle R, Dias M, Gray F. Dengue: neuropathological findings in 5 fatal cases from Brazil. Clin Neuropath. 1990;9(3):157-62.

34. Vasconcelos PFC, Travassos da Rosa APA, Coelho ICB, Menezes DB, Travassos da Rosa EST, Rodrigues SG, et al. Involvement of the central nervous system in dengue fever: three serologically confirmed cases from Fortaleza, Ceará. Rev Inst Med Trop São Paulo. 1998; 40(1):35-9.

35. Miagostovich MP, Ramos RG, Nicol AF, Nogueira RMR, Cuzzi-Maya T, Oliveira AV, et al. Retrospective study on dengue fatal cases. Clin Neuropathol. 1997;16(4):204-8.

36. Nogueira RMR, Filippis AMB, Coelho JMO, Sequeira PC, Schatzmayr HG, Paiva FG, et al. Dengue virus infection of the central nervous system (CNS): a case report from Brazil. Southeast Asian J Trop Med Public Health. 2002;33(1):68-71.

37. Ferreira MLB, Cavalcanti CG, Coelho CA Mesquita SB. Manifestações neurológicas de dengue: estudo de 41 casos. Arq Neuropsiquiatr. 2005;63(2-B): 488-93.

38. Brazil. Ministério da Saúde. Nota técnica: Surto de encéfalo-mielite aguda associada à infecção pelo vírus da dengue em municípios do Estado de Rondônia. 2005. Accessed on 10 December 2005 at http://portal.saude.gov. br/portal/arquivos/pdf/nota_dengue.pdf

39. Silva JB, Pimenta FG Epidemiologia da dengue. In: de Souza, LJ, ed. Dengue: diagnóstico, tratamento e prevenção. Rio de Janeiro: Editora Rubio; 2007. Pp. 11-35.

Manuscript received on 28 June 2006. Revised version accepted for publication on 12 July 2007. 
RESUMEN En Brasil se han notificado 4243049 casos de dengue entre 1981 y 2006, de ellos 5817 casos de dengue hemorrágico/síndrome de choque por dengue (DH/SCD) y un total de 338 casos mortales. A pesar de que la enfermedad ha afectado a todas las regiones

\section{Virus del dengue en Brasil,} 1986-2006

Palabras clave brasileñas, el mayor número de casos se ha notificado en las regiones nororiental y suroriental. Los virus del dengue (DENV) 1 y 4 se aislaron por primera vez en la región amazónica de Brasil en 1981 y 1982. La enfermedad se convirtió en un problema nacional de salud pública después de los brotes de DENV-1 y DENV-2 en el Estado de Río de Janeiro en 1986 y 1990, respectivamente. La introducción del DENV-3 en 2000, también en el Estado de Río de Janeiro, llevó a una grave epidemia con 288245 casos notificados de dengue y 91 muertes. Las cepas del virus identificadas durante la epidemia de 2002 demostraron que el DENV-3 ha desplazado a los otros serotipos y se ha expandido a nuevas zonas, algo que merece una evaluación más profunda. En los pacientes con dengue de al menos tres regiones del país se han observado síntomas clínicos atípicos, entre ellos alteraciones del sistema nervioso central.

Dengue, dengue/epidemiología, virus del dengue, diagnóstico, genoma viral, Brasil. 